\title{
Examining The Employment Intensity Of Economic Growth Of The PIIGS
}

\author{
William Seyfried, Rollins College, USA
}

\begin{abstract}
At the beginning of the second decade of the $21^{\text {st }}$ century, several countries in the periphery of Europe began suffering from sovereign debt crises, resulting from and contributing to economic weakness. As of late 2013, each country was struggling with double-digit unemployment rates with rates in Greece and Spain near 27\%. Though economic weakness was responsible for falling employment, the linkage between economic growth and employment, known as the employment intensity of economic growth (also called employment elasticity), may differ between nations. Estimation of models developed reveal different dynamics in the respective countries. Regardless of the model employed, the results revealed a very high employment intensity of economic growth in Spain relative to the other nations, indicating that employment was highly sensitive to changes in economic growth. As such, an equivalent decline in GDP had a much larger impact on employment in Spain than the other PIIGS. There is evidence that the structure of the labor market may play some role in explaining different employment elasticities for the countries in question. In particular, the degree of unionization appeared to be negatively correlated with employment intensity (economic growth had a smaller impact on employment in nations that have a larger percentage of unions) while the portion of workers on temporary contracts was positively correlated with employment intensity; countries with a larger percentage of workers on temporary contracts, such as Spain, had a higher employment intensity as employment responded more to changes in economic growth.
\end{abstract}

Keywords: Employment Intensity; Employment Elasticity; Economic Growth

\section{INTRODUCTION}

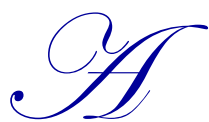

s the 1990s came to an end, many were looking forward to a new era for Europe as the euro was introduced. It was hoped that a common currency would lead to increased trade and capital flows, resulting in faster economic growth. Some of the main beneficiaries were expected to be those in the periphery of Europe. As the new century unfolded, growth did indeed accelerate in several countries, including Greece and Spain. Unfortunately, by the end of the decade, those in the periphery were experiencing sovereign debt crises and were now labeled the PIIGS - Portugal, Ireland, Italy, Greece, and Spain. Economic gains were wiped out as unemployment soared, exceeding $25 \%$ in Greece and Spain.

In this paper, we examine the relationship between economic growth, as measured by real GDP, and employment in the nations sometimes referred to as the PIIGS. A review of the existing literature on the topic is undertaken to provide both the underpinnings of the relationship as well as the context for the current research. Both the employment intensity of economic growth and the persistence of employment growth are estimated. Next, some of the factors that help explain the differences between nations are explored.

The period of this study begins in 1999 and ends in the fourth quarter of 2012. The statistical properties of each variable (the growth rates of employment and real GDP) are examined. Empirical models are then developed to estimate the employment intensity of economic growth. Employment intensities (the elasticity of employment with respect to real GDP) range from 0.2 to 0.4 (with one exception) in the nations considered for whom a significant relationship was found. Once the model is augmented to account for employment persistence, a smaller but still significant relationship is found for most of the countries considered. Next, the dynamic nature of the 
relationship between employment and economic growth is examined using impulse response analysis, providing further evidence of differences in the employment elasticities in the nations studied. Characteristics of the labor market help to explain some of the differences.

\section{REVIEW OF THE LITERATURE}

Several authors have estimated employment elasticities (a measure of the relationship between employment and economic growth) for a variety of nations. Significant differences in employment elasticities between different countries were detected by Padalino and Vivarelli (1997), with an elasticity of approximately 0.5 for the United States and Canada while elasticities for Japan, France, Germany, Italy, and the UK were close to zero. Pini (1997) estimated that the employment elasticities in Germany and Japan rose between the period 1979-95 compared to 1960-79 while it declined in France and Sweden and showed little change in Italy, UK, and US. He also detected negative employment elasticities in Italy and Sweden for the period 1990-95. Elasticities in the order of 0.5 to 0.6 for a set of OECD countries were detected by Boltho and Glyn (1995). In a study of industrialized countries by the International Labour Organization Report (1996), a country-by-country analysis revealed mixed results with little relationship found in Germany, Italy, and the UK in the 1990s, thus implying a jobless recovery. It also concluded that the responsiveness of employment growth to GDP growth has not declined in industrialized countries as a whole. Evidence suggesting that restructuring of major economic sectors reduced the relationship between economic growth and employment was discovered by Pianta, Evangelista, and Perani (1996). Among the G7 countries studied (Canada was excluded), a positive and significant relationship between growth in value added and employment was found only in Germany and the US. Walterskirchen (1999) found employment elasticities for the EU of 0.65 when employing a cross-country analysis of EU countries from 1988-98. Using data from 1970-98 for seven countries plus the EU as a whole, employment elasticities ranged from 0.24 for Austria to 0.76 for Spain (the elasticity for the US was 0.53 ).

Though some work has been conducted applying this technique to multinational studies, it typically does not account for employment persistence. The absence of this key component of the model may lead to misleading and biased results. Results of such an analysis should provide insight into the differences in the behavior of national labor markets as well as increased understanding as to why employment in different nations may respond differently to changes in economic growth. Furthermore, the dynamic nature of the relationship has received scant attention in the literature. A time-series model is developed to capture the total response of employment to economic growth, not just the response for one period.

There has been little empirical work concerning the factors affecting the employment intensity of economic growth, but some previous studies help to provide some insight. Walterskirchen (1999) found that a higher growth of the labor supply tends to raise employment and reduce productivity, thus suggesting a higher level of employment intensity of economic growth. Mourre (2006) found that employment intensity tends to be highest in the service sector, suggesting that nations with large service sectors should exhibit higher employment intensities.

\section{DESCRIPTIVE STATISTICS}

Quarterly data from 1999 to 2012 for both national employment and real GDP were obtained from $O E C D$ Statistics. ${ }^{1}$ As can be seen in Table 1a, the nations exhibited different patterns of economic growth during the study period. Italy and Portugal had the slowest average quarterly growth rates of $0.5 \%$ (measured at an annualized rate) while Ireland had the highest rate, $2.9 \%$. Ireland also displayed the highest median quarterly growth rate of $2.2 \%$, slightly above Greece and Spain, both of which were close to $2 \%$. Portugal was the laggard once more at about $0.5 \%$. Ireland also exhibited the most volatility when it came to economic growth. In terms of employment growth, Spain had the highest average quarterly growth rate, $1.3 \%$, slightly ahead of Ireland. Greece and Portugal both had negative average employment growth rates, $-0.6 \%$ and $-0.5 \%$, respectively. Portugal also had the weakest median employment growth rate of approximately $0 \%$ while Spain exhibited the highest median employment growth rate of $3.1 \%$. Spain and Ireland experienced the highest volatility in terms of employment growth while Italy was the most stable (See Table 1b).

${ }^{1}$ OECD Statistics can be found at http://stats.oecd.org 
Table 1a: Descriptive Statistics: Economic Growth

\begin{tabular}{|l|c|c|c|}
\hline & Mean & Median & Standard Deviation \\
\hline Greece & $1.97 \%$ & $2.06 \%$ & 5.06 \\
\hline Ireland & $2.93 \%$ & $2.22 \%$ & 7.65 \\
\hline Italy & $0.50 \%$ & $1.01 \%$ & 3.08 \\
\hline Portugal & $0.49 \%$ & $0.47 \%$ & 3.71 \\
\hline Spain & $1.40 \%$ & $2.02 \%$ & 2.74 \\
\hline
\end{tabular}

Table 1b: Descriptive Statistics: Employment Growth

\begin{tabular}{|l|c|c|c|}
\hline & Mean & Median & Standard Deviation \\
\hline Greece & $-0.62 \%$ & $0.47 \%$ & 3.69 \\
\hline Ireland & $1.26 \%$ & $2.16 \%$ & 4.17 \\
\hline Italy & $0.76 \%$ & $0.79 \%$ & 1.59 \\
\hline Portugal & $-0.48 \%$ & $0.04 \%$ & 2.47 \\
\hline Spain & $1.30 \%$ & $3.13 \%$ & 4.32 \\
\hline
\end{tabular}

\section{METHODOLOGY AND EMPIRICAL MODEL}

Following the approach undertaken by Boltho and Glynn (1995) and Padaline and Vivarelli (1997), the employment intensity of economic growth is estimated using the following model:

employgrowth $=\mathrm{B}_{0}+\mathrm{B}_{1}$ economic growth $+\varepsilon$

where:

Employgrowth is the annual percent change in employment for the respective nation, economic growth is the annual growth rate of real GDP, and $\mathrm{B}_{1}$ is the estimated employment elasticity.

The estimated elasticity provides a measure of the employment intensity of economic growth. In other words, how much growth in employment results from a one-percent growth in output? A high employment intensity indicates that growth in output leads to considerable job creation while low estimates of employment intensity suggest little correlation between economic growth and employment.

Though the model as expressed in (1) is traditionally used to estimate the employment elasticity of economic growth, it can be augmented to obtain other dynamics. For example, the inclusion of lagged employment growth allows one to obtain an estimate of the persistence of employment growth; i.e., does positive employment growth in one period tend to lead to positive employment growth in a subsequent period?

employgrowth $=\mathrm{B}_{0}+\mathrm{B}_{1}$ economic growth $+\mathrm{B}_{2}$ lagged employgrowth $+\varepsilon$

where:

$\mathrm{B}_{2}$ represents the degree of persistence in employment growth while $\mathrm{B}_{1}$ is the partial elasticity of employment with respect to economic growth.

Expanding on the model specified in (2), the appropriate lag structure of both employment and economic growth are determined followed by an impulse analysis to identify the total response of employment to economic growth as opposed to the response from just one period. The model takes the form:

employgrowth $=\mathrm{B}_{0}+\mathrm{B}_{1 \mathrm{i}}$ economic growth $(\mathrm{t}-\mathrm{i})+\mathrm{B}_{2 \mathrm{j}}$ employgrowth $(\mathrm{t}-\mathrm{j})+\varepsilon$

where:

$\mathrm{i}=0$ to $\mathrm{n}$

$\mathrm{j}=1$ to $\mathrm{n}$ 
Thus, current economic growth is an independent variable as well as its lagged value(s). Akaike's information criterion was used to determine the number of lags for both employment and economic growth. Each of the respective models was estimated with the results discussed in the next section. ${ }^{2}$

\section{EMPIRICAL RESULTS}

In the base model as described by (1), the results show that economic growth explains employment growth in all of the countries in question at the $1 \%$ level of significance. The estimated coefficients for three of the countries (Greece, Ireland, and Italy) were very similar, ranging from 0.22 to 0.26 , while Portugal was slightly higher at 0.37 (see Table 2). However, Spain's employment elasticity was considerably higher at nearly 1.45.

Table 2: Model with Economic Growth

\begin{tabular}{|l|c|c|}
\hline & constant & Economic Growth \\
\hline Greece & -0.014 & ${ }^{* * * *} 0.224$ \\
\hline Ireland & 0.118 & ${ }^{* * * *} 0.261$ \\
\hline Italy & 0.651 & 0.240 \\
\hline Portugal & ${ }^{* * * * *} 0.640$ & 0.373 \\
\hline Spain & -1.411 & 1.446 \\
\hline
\end{tabular}

As expected, the incorporation of lagged employment growth as an independent variable reduced the size of the estimated employment elasticity, though most remained significant at the $1 \%$ level, with the exception of Ireland, which was significant at the 5\% level and Greece, which was no longer significant (see Table 3). Ireland's employment elasticity was the lowest of those that were significant, 0.12 , while Spain's remained the higher at 1.09. All of the nations displayed persistence in employment growth, with significance at either the $1 \%$ or 5\% level. The degrees of persistence ranged from a low of 0.27 in Spain to a high of 0.71 in Ireland. This suggests that, if both Ireland and Spain experienced employment growth in the previous quarter, Ireland is more likely to continue that trend this quarter compared to Spain.

Table 3: Model with Economic Growth and Lagged Employment Growth

\begin{tabular}{|l|c|c|c|}
\hline \multicolumn{1}{|c|}{ Nation } & Constant & Economic Growth & Lagged Employment Growth \\
\hline Greece & -0.151 & 0.085 & ${ }^{* * * *} 0.632$ \\
\hline Ireland & -0.128 & 0.117 & 0.714 \\
\hline Italy & 0.420 & ${ }^{* * * *} 0.198$ & ${ }^{* * *} 0.307$ \\
\hline Portugal & -0.491 & ${ }^{* * * *} 0.292$ & 0.428 \\
\hline Spain & ${ }^{* * * * * *}-1.126$ & 1.087 & 0.266 \\
\hline
\end{tabular}

where ${ }^{* * *}$ indicates significance at the $1 \%$ level; ${ }^{* *}$ indicates significance at the $5 \%$ level, and ${ }^{*}$ indicates significance at the $10 \%$ level.

When using AIC to determine the appropriate lag structure, in most cases, the appropriate independent variables were found to be economic growth, lagged economic growth, and lagged employment growth, with the exception of Portugal in which employment growth lagged two periods was included. As with the second model, the employment elasticity with respect to current economic growth was significant for all but Greece (See Table 4). Lagged economic growth proved to be significant for Greece, as well as Ireland and Portugal, while lagged employment growth was significant for Greece, Ireland, and Italy. As implied earlier, employment growth lagged two periods was significant for Portugal.

Table 4: Model including Appropriate Lag Structure (as Determined by AIC)

\begin{tabular}{|l|c|c|c|c|c|}
\hline & constant & Economic Growth & $\begin{array}{c}\text { Economic Growth } \\
(\mathbf{t}-\mathbf{1})\end{array}$ & $\begin{array}{c}\text { Employment Growth } \\
(\mathbf{t}-\mathbf{1})\end{array}$ & $\begin{array}{c}\text { Employment Growth } \\
(\mathbf{t}-\mathbf{2})\end{array}$ \\
\hline Greece & -0.356 & 0.073 & 0.132 & ${ }^{* * *} 0.506$ & \\
\hline Ireland & -0.519 & ${ }^{* * *} 0.156$ & ${ }^{* * *} 0.134$ & ${ }^{* * * *} 0.560$ & \\
\hline Italy & 0.435 & 0.155 & 0.090 & 0.251 & \\
\hline Portugal & ${ }^{* * *}-0.554$ & ${ }^{* * * *} 0.246$ & 0.144 & 0.178 & \\
\hline Spain & ${ }^{* * * *}-1.300$ & ${ }^{* * * * *} 1.034$ & 0.229 & 0.170 & 0.308 \\
\hline
\end{tabular}

where ${ }^{* * *}$ indicates significance at the $1 \%$ level; ${ }^{* *}$ indicates significance at the $5 \%$ level, and ${ }^{*}$ indicates significance at the $10 \%$ level.

${ }^{2}$ Standard econometric tests revealed no indication of econometric problems such as serial correlation, heteroskedasticity, stationarity, or parameter instability. 
The results suggest that there are different responses of the respective labor markets to economic growth. In Greece, employment appears to have a mild reaction to economic growth with a lag while also displaying a relatively high degree of persistence. In other words, once employment starts heading in a particular direction, it is likely to continue for some time. Economic growth has both a contemporaneous and lagged impact on employment in both Ireland and Portugal. Both have some persistence in employment growth, particularly Ireland (with one lag while Portugal's lag extends for two periods). Italy's employment growth is significantly related to contemporary economic growth, but not lagged economic growth, while also showing some persistence. Spain stands out as having a noticeably higher employment elasticity than the others, regardless of which model was used, while also exhibiting the least degree of persistence (significant in one model but insignificant in the model determined by AIC).

\section{FACTORS AFFECTING EMPLOYMENT INTENSITY}

Given that the employment intensity of economic growth differs between nations, the question arises - why does this take place? One possible reason is the different industrial structure of the respective economies in terms of the proportion of service, manufacturing, and agricultural jobs. Given that productivity gains tend to be higher in manufacturing than services, it takes more economic growth to generate jobs in a manufacturing-based economy. As a result, economies that have relatively large manufacturing sectors would be expected to have lower employment elasticities (likewise, economies with relatively large service sectors are expected to have higher employment elasticities). Another factor that may result in different employment elasticities is the size of government employment compared to overall employment. It is likely that companies in the private sector will be more economically sensitive than the government when considering whether to expand or reduce employment. Thus, nations with a larger portion of government employment are expected to have lower employment elasticities.

Flaig and Rottmann (2007) found that the degree of labor market flexibility affected employment intensity such that economies with more flexible labor markets had lower employment elasticities. The portion of workers on temporary contracts is likely to be highly correlated with the employment elasticity since, when an economy is strong, companies can add workers while when growth weakens, it's easier to reduce employment (compared to those with longer-term contracts). On the flip side, the degree of unionization is likely to be inversely related to the employment intensity of economic growth since adjustments in employment are likely to be more difficult in response to changes in economic growth (for example, it is more difficult to reduce employment in response to an economic slowdown in the presence of strong union power).

Identifying the relative role of each of the aforementioned factors is limited by the sample size. That said, simple correlation analysis can provide some insight. Though different estimates of employment intensity were found given the slightly different models described above, the results tended to be similar. For the correlation analysis, the results of the model incorporating lagged employment growth were used. The variable most highly correlated with employment intensity was the degree of unionization, with a correlation coefficient of -0.72 followed by the portion of workers on temporary contracts, with a correlation coefficient of +0.49 . The other variables in question displayed little correlation (government employment had a correlation of +0.11 and the size of the service sector had a correlation of 0.03 , perhaps due to low variation in terms of the relative size of the service sector in the respective nations).

\section{SUMMARY AND CONCLUSIONS}

At the beginning of the second decade of the $21^{\text {st }}$ century, several countries in the periphery of Europe began suffering from sovereign debt crises resulting from and contributing to economic weakness. As of late 2013, each country was struggling with double-digit unemployment rates with rates in Greece and Spain near 27\%. Estimation of models developed reveal different dynamics in the respective countries. While traditional models seek to estimate the contemporaneous relationship between employment and economic growth, augmented models were introduced to account for employment persistence as well as lagged effects of economic growth on employment. Inclusion of lagged employment growth and lagged economic growth resulted in declines in the estimated elasticity of economic growth, though it was still significant in most cases. In addition, employment persistence was detected in all countries studied. 
Regardless of the model employed, the results revealed a very high employment elasticity in Spain relative to the other nations, indicating that employment was highly sensitive to economic growth. As such, an equivalent decline in GDP had a much larger impact on employment in Spain than the other PIIGS. Thus, though Portugal had a similar decline in GDP over time compared to Spain (about 5.5\% for each), Portugal experienced a smaller reduction in employment (12.9\% for Portugal compared to $17.2 \%$ in Spain). Meanwhile Greece, which had a smaller employment elasticity that operated with a lag, didn't experience sizeable declines in employment until later as large declines in GDP took place (a 20\% decline in GDP resulted in a 19.3\% decline in employment). There is evidence that the structure of the labor market may play some role in explaining different employment elasticities for the countries in question. In particular, the degree of unionization appeared to be negatively correlated with employment intensity (economic growth had a smaller impact on employment in nations that have a larger percentage of unions) while the portion of workers on temporary contracts was positively correlated with employment intensity (countries with a larger number of workers on temporary contracts, such as Spain, had a higher employment intensity as employment responded more to changes in economic growth).

The results of this study shows that the labor markets in each country display different underlying dynamics as changes in economic growth affect employment in different ways with employment being quite sensitive to economic growth in some countries with a weaker relationship in others. There is some evidence that certain characteristics of the labor market, such as degree of unionization and the portion of workers on temporary contracts, help to explain differences in the employment intensity of economic growth.

\section{AUTHOR INFORMATION}

William Seyfried is a Professor of Economics at the Crummer Graduate School of Business at Rollins College in Winter Park, Florida. His main research interests are examining the behavior of various aspects of the macroeconomy, including economic growth, employment, and financial markets. E-mail: wseyfried@ rollins.edu

\section{REFERENCES}

1. Boltho, A., \& Glyn, A. (1995). Can macroeconomic policies raise employment? International Labour Review, 134, 451-470.

2. Flaig, G., \& Rottmann, H. (2007). Labor market institutions and the employment intensity of output growth, an international comparison. (Cesifo Working Paper No, 2175). Retrieved from http://www.cesifogroup.ed/portal/pls/portal/docs/1/1187292.pdf

3. International Labour Organization (1996). World employment 1996/97: National Policies in a global context. International Labour Office.

4. $\quad$ Kennedy, P. (1998). A Guide to econometrics $\left(4^{\text {th }}\right.$ ed.). Cambridge, MA: The MIT Press.

5. Mourre, G. (2006). Did the pattern of aggregate employment growth change in the Euro area in the late 1990s? Applied Economics, 38, 1783-1807.

6. Padalino, S., \& Vivarelli, M. (1997). The employment intensity of economic growth in the G-7 countries. International Labour Review, 136, 191-213.

7. Pianta, M., Evangelista, R., \& Perani, G. (1996). The dynamics of innovation and employment: An international comparison. Science Technology Industry Review, 18, 67-93.

8. Pini, P. (1997). Occupazione, tecnologia e crescita: Modelli interpretativi ed eevidenze empiriche a livello macroeconomico. 1997. Paper Presented to the Conference of the Accademia Nazionale dei Lincei on "Sviluppo tecnologico e disoccupazione: Trasformazione della societa", held in Rome, 16-18 January 1997.

9. Walterskirchen, E. (1999). The relationship between growth, employment and unemployment in the EU. European Economist for an Alternative Economic Policy Workshop, Barcelona, Spain. Retrieved from http://www.memo-europe.uni-bremen.de/tser/Walterskirchen_24months.PDF 